\title{
Structural and Computational Studies of 1-Methyl-2-thiocytosine and its Coordination Mode in a Dinuclear Platinum(IV) Complex $\left[\left(\mathrm{PtMe}_{3}\right)_{2}\left(\mu-1-\mathrm{MeSCy}-1 \kappa N^{3}, 1: 2 \kappa^{2} S\right)_{2}\right]\left[\mathrm{BF}_{4}\right]_{2}$
}

\author{
Cornelia Vetter $^{\mathrm{a}}$, Christoph Wagner ${ }^{\mathrm{a}}$, Ralph Kluge ${ }^{\mathrm{b}}$, and Dirk Steinborn ${ }^{\mathrm{a}}$ \\ ${ }^{a}$ Institut für Chemie - Anorganische Chemie, Martin-Luther-Universität Halle-Wittenberg, \\ Kurt-Mothes-Straße 2, 06120 Halle, Germany \\ b Institut für Chemie - Organische Chemie, Martin-Luther-Universität Halle-Wittenberg, \\ Kurt-Mothes-Straße 2, 06120 Halle, Germany
}

Reprint requests to Prof. D. Steinborn. Tel.: +345 5525620. Fax: +345 5527028.

E-mail: dirk.steinborn@chemie.uni-halle.de

Z. Naturforsch. 2010, 65b, 578 - 586; received January 20, 2010

\begin{abstract}
X-Ray diffraction analysis of 1-methyl-2-thiocytosine (1-MeSCy, 1) revealed that its crystals contain two structurally very similar independent molecules (A,B). These molecules are connected through a complex network of hydrogen bonds. Centrosymmetric di- and tetrameric units $\mathrm{AA}^{\prime}$ and $\mathrm{BAA}^{\prime} \mathrm{B}^{\prime}$, respectively, are formed through $\mathrm{N}-\mathrm{H} \cdots \mathrm{N}$ hydrogen bonds $\left(\mathrm{N} 4 \mathrm{a} \cdots \mathrm{N} 3 \mathrm{a}^{\prime} 3.019(4) \AA \mathrm{A}^{\prime}\right.$; $\left.\mathrm{N} 4 \mathrm{a} \cdots \mathrm{N} 3 \mathrm{~b} 2.988(4) \AA, \mathrm{BAA}^{\prime} \mathrm{B}^{\prime}\right)$, and the tetrameric units are connected through $\mathrm{N}-\mathrm{H} \cdots \mathrm{S}$ hydrogen bonds. The arrangement of A and B molecules found in crystals of 1 was confirmed by DFT calculations up to tetrameric $\mathrm{BAA}^{\prime} \mathrm{B}^{\prime}$ units, yielding similar equilibrium structures, and the energies of the $\mathrm{N}-\mathrm{H} \cdot \mathrm{N}$ hydrogen bonds between $\mathrm{A}$ and $\mathrm{A}^{\prime}$ and $\mathrm{A}$ and $\mathrm{B}$ were calculated to be about $10 \mathrm{kcal} \mathrm{mol}^{-1}$. Reaction of 1-MeSCy (1) with $\left[\mathrm{PtMe}_{3}\left(\mathrm{Me}_{2} \mathrm{CO}\right)_{3}\right]\left[\mathrm{BF}_{4}\right]$ (2) led to the formation of the ionic dinuclear complex $\left[\left(\mathrm{PtMe}_{3}\right)_{2}\left(\mu-1-\mathrm{MeSCy}-1 \kappa N^{3}, 1: 2 \kappa^{2} S\right)_{2}\right]\left[\mathrm{BF}_{4}\right]_{2}(3)$ which was fully characterized by NMR $\left({ }^{1} \mathrm{H},{ }^{13} \mathrm{C},{ }^{195} \mathrm{Pt}\right)$ and IR spectroscopy, ESI mass spectrometry and microanalysis. A singlecrystal X-ray diffraction analysis of $\mathbf{3}$ confirmed the dinuclear structure of the complex. The complex cation consists of a central $\left[\mathrm{Pt}_{2}(\mu-\mathrm{S})_{2}\right]$ core having bound the 1-methyl-2-thiocytosine ligands in a $1 \kappa N^{3}, 1: 2 \kappa^{2} S$ coordination mode in a face-to-face arrangement, the thionucleobase ligands being present as the amino-thione tautomer.
\end{abstract}

Key words: Thionucleobases, Platinum Complexes, Hydrogen Bonding, Single-crystal X-Ray Diffraction Analysis, DFT Calculations

\section{Introduction}

Thionucleobases and thionucleosides can be found in many biological processes. 2-Thiouracil has been found in t-RNA of E. coli bacteria [1]. Furthermore, the nucleosides of 4-thiouracil and 2-thiocytosine are present in t-RNA of several sources [2-5]. Further insight into the function of these compounds can be achieved by investigations of model compounds. The most simple models for these nucleosides are the derivatives methylated at the position next to the carbohydrate moiety. They should exist in the same tautomeric form as the requisite nucleosides. Depending on the solvent, thionucleobases can exist as many different tautomers. For 2-thiocytosine, in particular, it has been found that in aqueous solution and polycrys- talline films the thione-amino tautomer is the predominant species [6-9]. In accordance with these observations the thione-amino form is present in crystals of 2-thiocytosine [10]. Methylation of a nucleobase limits the number of possible tautomers and may severely influence the resulting hydrogen bonding pattern. Metal coordination of thionucleobases is also of particular interest [11], especially because the coordination behavior of thionucleobases has not been studied as extensively as that of the naturally occurring oxygen analogs. It has been shown that metal thionucleobase complexes exhibit interesting bioactive properties [12]. Here we report the crystal structure of 1-methyl-2thiocytosine (1) as well as the synthesis and the crystal structure of its ionic, dinuclear platinum(IV) complex $\left[\left(\mathrm{PtMe}_{3}\right)_{2}\left(\mu-1-\mathrm{MeSCy}-1 \kappa N^{3}, 1: 2 \kappa^{2} S\right)_{2}\right]\left[\mathrm{BF}_{4}\right]_{2}(\mathbf{3})$. 
a)

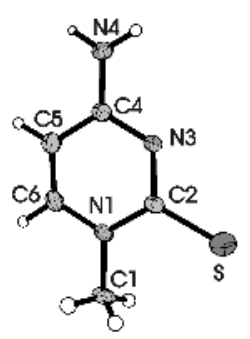

b)

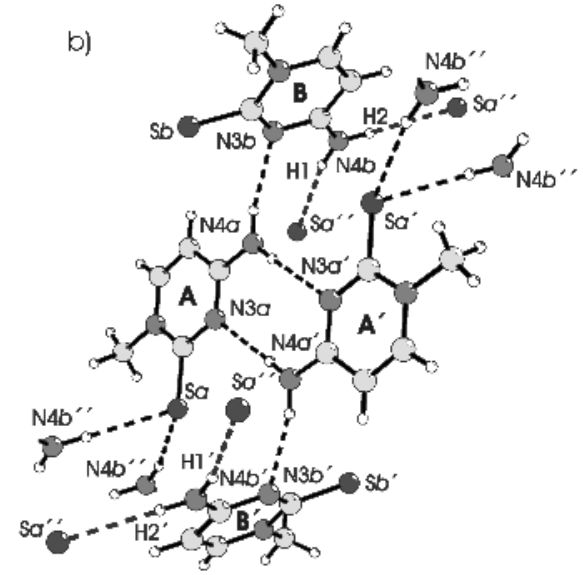

c)

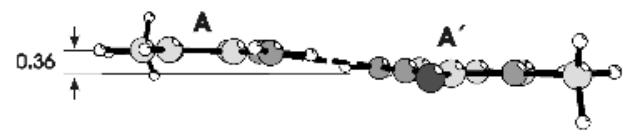

Fig. 1. a) Molecular structure of one of the two crystallographically independent monomeric 1-methyl-2-thiocytosine units in crystals of $\mathbf{1}$. The displacement ellipsoids are drawn at the $30 \%$ probability level. b) Hydrogen bonding in crystals of 1. All atoms which do not belong to the $\mathrm{BAA}^{\prime} \mathrm{B}^{\prime}$ unit are doubly primed. c) Side view of the centrosymmetric $\mathrm{AA}^{\prime}$ dimer (1-MeSCy $)_{2}$.

\section{Results and Discussion}

\section{Crystal structure of 1-methyl-2-thiocytosine (1)}

Colorless needles of 1-methyl-2-thiocytosine (1MeSCy, 1) were obtained from an ethanol solution. The compound crystallizes in the centrosymmetric space group $P 2_{1} / n$. The crystals contain two crystallographically independent molecules of 1-MeSCy (A, B) which are structurally very similar (Fig. 1 and Table 1 ). Within the $3 \sigma$ criterion all corresponding bonds in $\mathrm{A}$ and $\mathrm{B}$ as well as most of the angles are equivalent.

In crystals of $\mathbf{1}$ a network of hydrogen bonds connects the monomeric molecules $\mathrm{A}$ and $\mathrm{B}$. Basically, two molecules of A build up a centrosymmetric dimer $\mathrm{AA}^{\prime}$ through two $\mathrm{N} 4 a-\mathrm{H} \cdots \mathrm{N} 3 a^{\prime}$ hydrogen bonds (Fig. 1, Table 1). The $\mathrm{AA}^{\prime}$ dimer is not planar, but the monomers are shifted parallel by $0.36 \AA$. Such a shift by as much as $1.41 \AA$ was also found in crystals of 1-methylcytosine $[13,14]$. The $\mathrm{N} 4 a \mathrm{H}_{2}$ amino groups generate further hydrogen bonds to N3b (Table 1). Thus, a centrosymmetrical tetrameric unit $\mathrm{BAA}^{\prime} \mathrm{B}^{\prime}$ is formed. The $\mathrm{B}$ molecules are nearly perpendicular to the $\mathrm{AA}^{\prime}$ dimers (interplanar angle: $86.4(8)^{\circ}$ ). Interestingly, the $\mathrm{N} 4 a-\mathrm{H}$ vector forms an angle of $34.9^{\circ}$ with the pyrimidine plane of molecule B. Thus, in the hydrogen bond $\mathrm{N} 4 a-\mathrm{H} \cdots \mathrm{N} 3 b$ the lone pair of electrons on $\mathrm{N} 3 b$ is not directed towards the central $\mathrm{H}$ atom. In addition, the sulfur atoms $\mathrm{S} a$ act as hydrogen acceptors
Table 1. Selected bond lengths and angles of molecules A and $\mathrm{B}^{\mathrm{a}}$ and structural parameters of hydrogen bonds in crystals of 1-MeSCy (1) (distances in $\AA$, angles in deg).

\begin{tabular}{|c|c|c|c|c|}
\hline $\mathrm{C} 1-\mathrm{N} 1$ & \multicolumn{2}{|c|}{$1.477(3) / 1.475(4)$} & C4-N4 & $1.327(3) / 1.338(4)$ \\
\hline $\mathrm{C} 2-\mathrm{N} 1$ & \multicolumn{2}{|c|}{$1.381(3) / 1.390(3)$} & $\mathrm{C} 4-\mathrm{C} 5$ & $1.423(4) / 1.422(4)$ \\
\hline $2-S$ & \multicolumn{2}{|c|}{$1.702(3) / 1.692(3)$} & C5-C6 & $1.338(4) / 1.335(4)$ \\
\hline $2-\mathrm{N} 3$ & \multicolumn{2}{|c|}{$1.344(3) / 1.343(3)$} & C6-N1 & $1.371(3) / 1.358(4)$ \\
\hline $4-\mathrm{N} 3$ & \multicolumn{3}{|c|}{$1.343(3) / 1.334(3)$} & \\
\hline $1-\mathrm{N} 1-\mathrm{C} 2$ & \multicolumn{2}{|c|}{$121.5(2) / 121.3(3)$} & $\mathrm{S}-\mathrm{C} 2-\mathrm{N} 3$ & $119.1(2) / 121.0(2)$ \\
\hline $2-\mathrm{N} 3-\mathrm{C} 4$ & \multicolumn{2}{|c|}{$120.9(2) / 120.4(2)$} & $\mathrm{N} 4-\mathrm{C} 4-\mathrm{N} 3$ & $117.8(2) / 118.1(2)$ \\
\hline$-\mathrm{C} 2-\mathrm{N} 1$ & \multicolumn{2}{|c|}{$121.3(2) / 119.6(2)$} & $\mathrm{C} 4-\mathrm{C} 5$ & 117.5( \\
\hline $\mathrm{D}-\mathrm{H} \cdot \mathrm{A}$ & \multicolumn{2}{|c|}{$\mathrm{N} 4 a-\mathrm{H} \cdot \cdot \mathrm{N} 3 a^{\prime} \quad \mathrm{N} 4 a-\mathrm{H} \cdot \cdot \mathrm{N} 3 b$} & $b \mathrm{~N} 4 b-\mathrm{H} 1 \cdot \cdot \mathrm{S} c$ & $\mathrm{~S} a^{\prime \prime} \mathrm{N} 4 b$ \\
\hline WA & $3.019(4)$ & $2.988(4)$ & $3.493(4)$ & 3.463 \\
\hline $\mathrm{D}-\mathrm{H}$ & 0.87 & 0.87 & 0.88 & 0.91 \\
\hline $\mathrm{H} \cdots \mathrm{A}$ & 2.16 & 2.14 & 2.64 & 2.55 \\
\hline $\mathrm{D}-\mathrm{H} \cdots \mathrm{A}$ & 174 & 165 & 164 & 173 \\
\hline
\end{tabular}

a The first value refers to molecule $\mathrm{A}$ and the second value to molecule B.

for the amino groups $\mathrm{N} 4 b \mathrm{H}_{2}$ of the $\mathrm{B}$ molecules yielding $\mathrm{N}-\mathrm{H} \cdots \mathrm{S}$ hydrogen bonds (Fig. 1, Table 1). On the other hand, the interaction of the sulfur atom $\mathrm{S} b$ with C6 $b-\mathrm{H}$ groups ( $\mathrm{S} b \cdots \mathrm{C} 6 b 3.663(4) \AA, \mathrm{S} b \cdots \mathrm{H} 2.73 \AA$ ) is found to be in the border range of weak hydrogen bonds $[15,16]$.

The geometrical parameters of the four hydrogen bonds discussed (Table 1) are in accord with data given in the literature $[17,18]$. Thus, for $\mathrm{N}-$ $\mathrm{H} \cdots \mathrm{N}\left(s p^{2}\right)$ hydrogen bonds the median of the $\mathrm{N} \cdots \mathrm{N}$ distances was found to be $3.023 \AA$ (lower/upper quartile: $2.967 / 3.091 \AA$, for 1253 observations). For $\mathrm{N}-$ $\mathrm{H} \cdots \mathrm{S}=\mathrm{C}$ hydrogen bonds the median of the $\mathrm{N} \cdots \mathrm{S}$ 


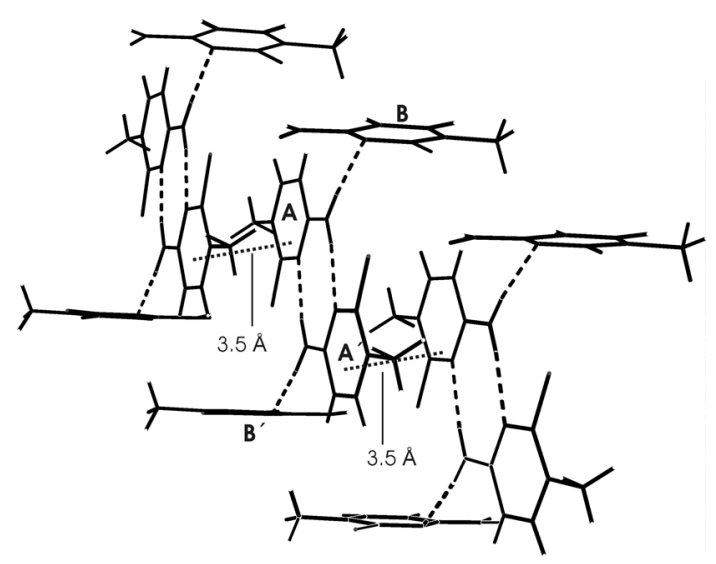

Fig. 2. Packing of molecules A and B and $\pi-\pi$ stacking $(\cdots)$ between $\mathrm{A}$ and $\mathrm{A}^{\prime}$ molecules in crystals of $\mathbf{1}$.

distances proved to be $3.467 \AA$ (lower/upper quartile: 3.408/3.551 $\mathrm{A}$, for 1873 observations) [17].

In crystals of $\mathbf{1}$ the dimeric units $\mathrm{AA}^{\prime}$ and the monomeric units $B$ are packed in infinitive strands like a "staircase", as shown in Fig. 2. Within the $\mathrm{AA}^{\prime}$ strands an interplanar ring distance of $3.5 \AA$ and a displacement angle of $17.5^{\circ}$ between pairs of pyrimidine rings of $\mathrm{A}$ indicate a stabilization through $\pi$ $\pi$ stacking and/or $\mathrm{C}-\mathrm{H}-\pi$ stacking [19]. Though a relatively short interplanar distance of $3.0 \AA$ between the molecules in the B strands was found, a displacement angle of $59.9^{\circ}$ of the $\mathrm{B}$ molecules suggests the absence of significant stabilization through $\pi-\pi / \mathrm{C}-\mathrm{H}-\pi$ interactions.

\section{Quantum-chemical calculations}

To gain insight into the strength of the hydrogen bonds that are found in crystals of 1-methyl-2thiocytosine (1), DFT calculations (using the B3LYP hybrid functional and $6-31++\mathrm{G}(\mathrm{d}, \mathrm{p})$ basis sets) of the monomeric 1-MeSCy $\mathbf{1 m}$, the doubly $\mathrm{N} 4-\mathrm{H} \cdots \mathrm{N} 3^{\prime}$ hydrogen-bonded dimer 1d and the tetramer 1t, having two further monomers attached to 1d through N4$\mathrm{H} \cdots \mathrm{N}^{\prime}$ hydrogen bonds, were performed. The equilibrium structures are shown in Fig. 3, selected structural parameters are given in Table 2. As Table 2 reveals, the involvement of $\mathbf{1 m}$ in a hydrogen-bonded system gives rise to only small structural changes.

Dimer 1d and tetramer $\mathbf{1 t}$ can be regarded as models for the dimer $\mathrm{AA}^{\prime}$ and the tetramer $\mathrm{BAA}^{\prime} \mathrm{B}^{\prime}$ found in the solid-state structure of $\mathbf{1}$. As shown in Table 2, there is good agreement of the calculated (1t) and the experimental structure (1). The most obvious differ-
Table 2. Calculated parameters (distances in $\AA$, angles in deg) of the monomeric 1-MeSCy (1m), the twofold hydrogenbridged dimer of the type $\mathrm{AA}^{\prime}(\mathbf{1 d})$ and the tetrameric unit of the type $\mathrm{BAA}^{\prime} \mathrm{B}^{\prime}(\mathbf{1 t})$. For comparison, the corresponding experimentally measured values in crystals of $\mathbf{1}$ are given.

\begin{tabular}{lllll}
\hline & $\mathbf{1 m}$ & $\mathbf{1 d}$ & $\mathbf{1 t}$ & $\mathbf{1}$ \\
\hline $\mathrm{C} 2-\mathrm{N} 1$ & 1.420 & 1.411 & $1.402 / 1.410^{\mathrm{a}}$ & $1.381(3) / 1.390(3)^{\mathrm{a}}$ \\
$\mathrm{C} 2-\mathrm{S}$ & 1.678 & 1.689 & $1.702 / 1.686$ & $1.702(3) / 1.692(3)$ \\
$\mathrm{C} 2-\mathrm{N} 3$ & 1.357 & 1.351 & $1.350 / 1.356$ & $1.344(3) / 1.343(3)$ \\
$\mathrm{C} 4-\mathrm{N} 3$ & 1.323 & 1.341 & $1.345 / 1.332$ & $1.343(3) / 1.334(3)$ \\
$\mathrm{C} 4-\mathrm{N} 4$ & 1.361 & 1.338 & $1.339 / 1.358$ & $1.327(3) / 1.338(4)$ \\
$\mathrm{N} 1-\mathrm{C} 2-\mathrm{N} 3$ & 117.5 & 118.0 & $118.8 / 118.0$ & $119.7(2) / 119.4(2)$ \\
$\mathrm{C} 2-\mathrm{N} 3-\mathrm{C} 4$ & 121.6 & 122.4 & $121.3 / 121.7$ & $120.9(2) / 120.4(2)$ \\
$\mathrm{N} 4 \cdots \mathrm{N} 3^{\prime}$ & & 2.948 & $3.063 / 3.161^{\mathrm{b}}$ & $3.019(4) / 2.988(4)^{\mathrm{b}}$ \\
$\mathrm{N} 4-\mathrm{H}$ & & 1.032 & $1.027 / 1.015$ & $0.87 / 0.87$ \\
$\mathrm{H} \cdots \mathrm{N} 3^{\prime}$ & & 1.916 & $2.038 / 2.200$ & $2.16 / 2.14$ \\
$\mathrm{~N} 4-\mathrm{H} \cdots \mathrm{N}^{\prime}$ & & 179.4 & $175.3 / 157.3$ & $174 / 165$ \\
\hline
\end{tabular}

${ }^{a}$ The first value refers to molecules $\mathrm{A}$ and the second value to molecules $\mathrm{B} ;{ }^{\mathrm{b}}$ the first value refers to hydrogen bonds in the dimers $\mathrm{AA}^{\prime}$ and the second value to the hydrogen bonding within units $\mathrm{AB}$.

ence is that the dimeric units $\mathrm{AA}^{\prime}$ in $\mathbf{1 d}$ and $\mathbf{1 t}$ were calculated to be (nearly perfectly) planar (greatest deviation from the mean plane: $0.003 \AA$ for $\mathrm{N} 4 a / \mathrm{N} 4 a^{\prime}$ ), whereas in $\mathbf{1}$ the two halves of the dimer are shifted parallel by $0.36 \AA$ (see Fig. 1). Furthermore, in the tetramer 1t the interplanar angle between the central dimeric unit $\left(\mathrm{AA}^{\prime}\right)$ and its attached monomers $\left(\mathrm{B} / \mathrm{B}^{\prime}\right)$ is found to be $36.9^{\circ}$, whereas in the solid-state structure of 1 the $\mathrm{B} / \mathrm{B}^{\prime}$ units are nearly perpendicular to the dimeric unit $\mathrm{AA}^{\prime}\left(86.4(8)^{\circ}\right)$. A tetrameric structure $1 \mathbf{t}^{\prime}$, obtained by a restricted optimization such that the interplanar angle between the $\mathrm{AA}^{\prime}$ unit and the $\mathrm{B} / \mathrm{B}^{\prime}$ molecules found in the experimental structure $\left(86.4^{\circ}\right)$ is obtained, proved to be only $6.2 \mathrm{kcal} \mathrm{mol}^{-1}$ higher in energy than the equilibrium structure 1t. As found in the experimental structure of $\mathbf{1}$, the free electron pair of $\mathrm{N} 3 b$ in the calculated structure $\mathbf{1 t}$ is not pointing directly towards the central $\mathrm{H}$ atom. However, the calculated angle between the $\mathrm{N} 4 a-\mathrm{H}$ vector and the mean plane of the pyrimidine ring $\left(22.8^{\circ}\right)$ is remarkably smaller than in crystals of $\mathbf{1}\left(34.9^{\circ}\right)$. This can be accounted for by further hydrogen bonds $(\mathrm{N}-\mathrm{H} \cdots \mathrm{S})$ and also $\pi-\pi$ stackings in crystals of $\mathbf{1}$ that were not taken into consideration in the calculations.

The strength of intermolecular hydrogen bonds, $\Delta H_{\mathrm{hb}}$, is defined as the enthalpy of the reaction

$$
\mathrm{X}-\mathrm{H} \cdots \mathrm{Y} \longrightarrow \mathrm{X}-\mathrm{H}+\mid \mathrm{Y}
$$

when all components are in their equilibrium conformations. The energies for the reactions

$$
\mathbf{1 d} \rightarrow 21 \mathrm{~m} \text { and } \mathbf{1 t} \rightarrow \mathbf{1 d}+21 \mathrm{~m}
$$




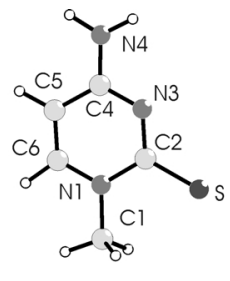

$1 \mathrm{~m}$

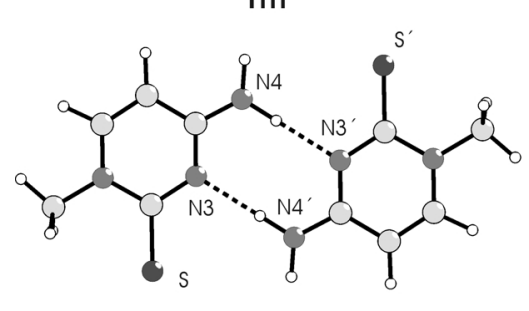

$1 d$

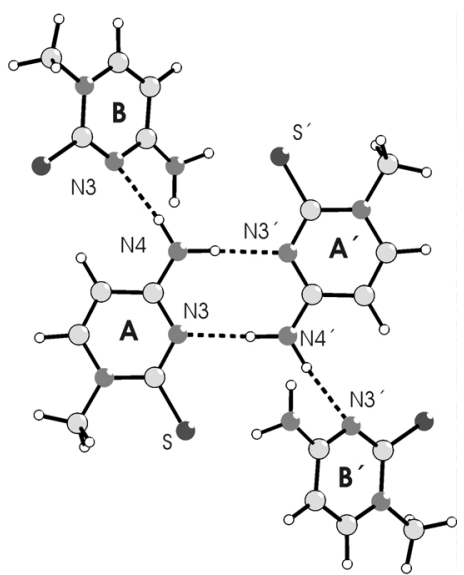

$1 \dagger$
Fig. 3. Calculated equilibrium structures of the monomeric 1-MeSCy (1m), the twofold hydrogen-bonded dimer of the type $\mathrm{AA}^{\prime}(\mathbf{1 d})$ and the tetrameric unit of the type $\mathrm{BAA}^{\prime} \mathrm{B}^{\prime}(\mathbf{1 t})$.

$2\left[\mathrm{PtMe}_{3}\left(\mathrm{Me}_{2} \mathrm{CO}\right)_{3}\right]\left[\mathrm{BF}_{4}\right](2) \stackrel{+21-\mathrm{MeSCy}(\mathbf{1})}{\stackrel{-6 \mathrm{Me}_{2} \mathrm{CO}}{\longrightarrow}}$

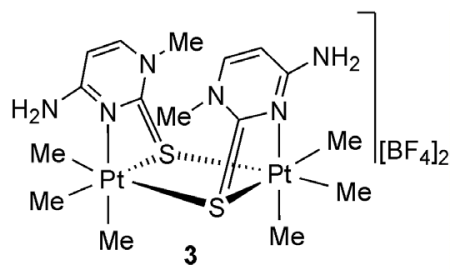

Scheme 1.

were found to be endothermic by 20.2 and $21.7 \mathrm{kcal} \mathrm{mol}^{-1}$, respectively. Considering basis BSSE set superposition errors [20], values of 19.4 and $19.6 \mathrm{kcal} \mathrm{mol}^{-1}$, respectively, were obtained. Thus, both types of the N4-H $\cdots \mathrm{N} 3^{\prime}$ hydrogen bonds, namely those building up the dimers and tetramers, are of approximately the same strength (about $10 \mathrm{kcal} \mathrm{mol}^{-1}$ per hydrogen bond). Thus, these hydrogen bonds are stronger than those in gaseous water dimers $\left(5.0 \mathrm{kcal} \mathrm{mol}^{-1}\right)[20,21]$ which are benchmarks for hydrogen bonds. Classifying hydrogen bonds with respect to their energies [22] (weak $<4$, moderate $4-15$, strong $14-40 \mathrm{kcal} \mathrm{mol}^{-1}$ ) they have to be regarded as moderate.

\section{Synthesis and spectroscopic characterization of $\left[\left(\mathrm{PtMe}_{3}\right)_{2}\left(\mu-1-\mathrm{MeSCy}-1 \kappa N^{3}, 1: 2 \kappa^{2} S\right)_{2}\right]\left[\mathrm{BF}_{4}\right]_{2}(\mathbf{3})$}

$\left[\mathrm{PtMe}_{3}\left(\mathrm{Me}_{2} \mathrm{CO}\right)_{3}\right]\left[\mathrm{BF}_{4}\right]$ (2) [23] was reacted with 1-methylthiocytosine (1) in acetone solution to yield $\left[\left(\mathrm{PtMe}_{3}\right)_{2}\left(\mu-1-\mathrm{MeSCy}-1 \kappa N^{3}, 1: 2 \kappa^{2} S\right)_{2}\right]\left[\mathrm{BF}_{4}\right]_{2}$

(Scheme 1). The slightly air- and moisture-sensitive complex was isolated in $56 \%$ yield. By contrast, the analogous reaction with 2-thiocytosine led to the formation of several products. Complex $\mathbf{3}$ was
Table 3. ${ }^{1} \mathrm{H}$ and ${ }^{13} \mathrm{C}$ NMR data $(\delta$ in ppm, $J$ in $\mathrm{Hz}$ ) of $1-$ $\operatorname{MeSCy}(\mathbf{1})$ and $\left[\left(\mathrm{PtMe}_{3}\right)_{2}\left(\mu-1-\mathrm{MeSCy}-1 \kappa N^{3}, 1: 2 \kappa^{2} S\right)_{2}\right](\mathbf{3})$ in $\mathrm{CD}_{3} \mathrm{OD}$.

\begin{tabular}{lcrcr}
\hline & & $\mathbf{1}$ & \multicolumn{2}{c}{$\mathbf{3}$} \\
& $\delta_{\mathrm{H}}$ & \multicolumn{1}{c}{$\delta_{\mathrm{C}}{ }^{\mathrm{b}}$} & $\delta_{\mathrm{H}}\left({ }^{2} J_{\mathrm{Pt}, \mathrm{H}}\right)$ & \multicolumn{1}{c}{$\delta_{\mathrm{C}}$} \\
\hline $\mathrm{H} 5 / \mathrm{C5}^{\mathrm{a}}$ & 6.09 & 97.0 & 6.53 & 101.8 \\
$\mathrm{H} 6 / \mathrm{C} 6$ & 7.73 & 146.8 & 7.98 & 147.8 \\
$\mathrm{~N} 1-\mathrm{CH}_{3}$ & 3.72 & 43.3 & 3.64 & 40.7 \\
$\mathrm{C} 2$ & & 180.6 & & 184.4 \\
$\mathrm{C} 4$ & & 160.5 & & 160.4 \\
$\mathrm{PtMe}_{3}$ & & & $1.22(75.5)^{\mathrm{c}}$ & -7.3 \\
\hline
\end{tabular}

${ }^{a}$ Numbering scheme according to Fig. 1a; ${ }^{b}$ due to insufficient solubility of $1-\mathrm{MeSCy}(\mathbf{1})$ the chemical shifts of $\mathbf{1}$ in $\left[\mathrm{D}_{6}\right] \mathrm{DMSO}$ are given; ${ }^{\mathrm{c}}$ at $-50{ }^{\circ} \mathrm{C}: 1.189 / 1.194 \mathrm{ppm}(74.7 / 81.5)$.

fully characterized by ${ }^{1} \mathrm{H},{ }^{13} \mathrm{C}$ and ${ }^{195} \mathrm{Pt}-\mathrm{NMR}$ spectroscopy, as well as by ESI-MS spectrometry, IR spectroscopy, and $\mathrm{X}$-ray diffraction analysis. Table 3 shows the ${ }^{1} \mathrm{H}$ and ${ }^{13} \mathrm{C}-\mathrm{NMR}$ data of $\left[\left(\mathrm{PtMe}_{3}\right)_{2}(\mu\right.$ 1-MeSCy- $\left.\left.1 \kappa N^{3}, 1: 2 \kappa^{2} S\right)_{2}\right]\left[\mathrm{BF}_{4}\right]_{2}$ (3). A remarkably downfield shift for the signals of $\mathrm{H} 5$ and the respective carbon atom $\mathrm{C} 5$ by 0.44 and $4.8 \mathrm{ppm}$, respectively, is observed. Moreover, the doublet of H5 exhibits platinum satellites $\left({ }^{4} J_{\mathrm{Pt}, \mathrm{H}}=11.6 \mathrm{~Hz}\right)$ indicating the involvement of N3 in platinum coordination [24]. The signals of H6/C6 are also shifted to lower field but to a lesser extent $(0.25 / 1.0 \mathrm{ppm})$, and no platinum satellites 


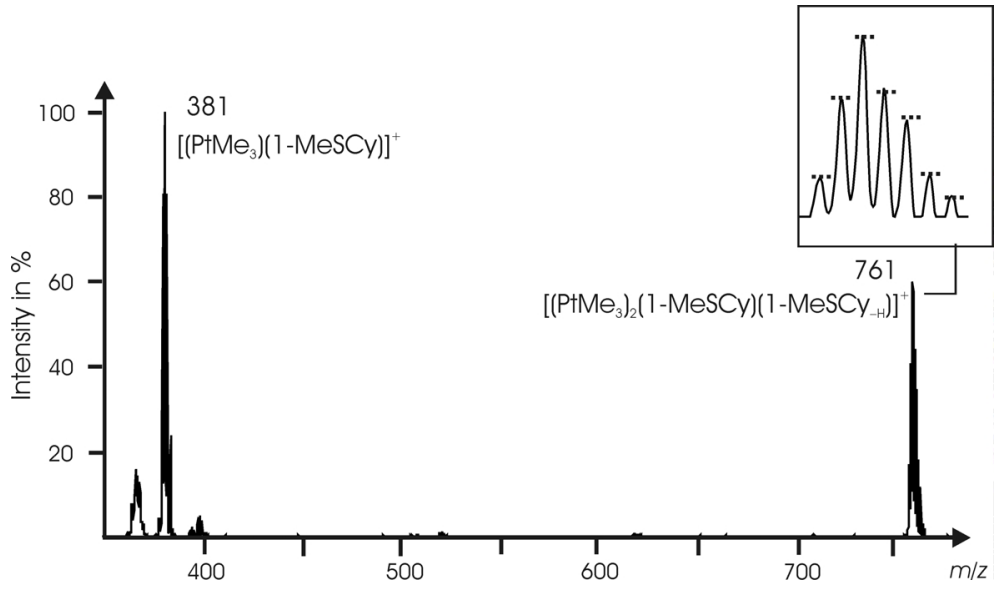

Fig. 4. Full scan mass spectrum of $\left[\left(\mathrm{PtMe}_{3}\right)_{2}(\mu-1-\mathrm{MeSCy}-\right.$ $\left.\left.1 \kappa N^{3}, 1: 2 \kappa^{2} S\right)_{2}\right]\left[\mathrm{BF}_{4}\right]_{2} \quad(3)$. Inset: isotopic pattern of the molecular ion $\left[\mathrm{PtMe}_{3}(1-\mathrm{MeSCy})\left(1-\mathrm{MeSCy}_{-\mathrm{H}}\right)\right]^{+}$at $\mathrm{m} / z=761$ showing the expected intensities due to the isotopic composition in horizontal bars. are found. The shift of the signal for $\mathrm{C} 2$ by $3.8 \mathrm{ppm}$ to lower field indicates the sulfur coordination to the platinum(IV) atom. Thus, from the NMR experiments a $\kappa N^{3}, \kappa S$ coordination could be derived, as definitely established by X-ray diffraction measurement (see below). For the protons of the three methyl ligands at room temperature only one sharp signal flanked by platinum satellites is found, whereas at $-50{ }^{\circ} \mathrm{C}$ a splitting into at least two singlets, flanked by platinum satellites, becomes apparent (Table 3).

ESI-MS measurements using acetone solutions have confirmed the presence of a dinuclear cation $\left[\left(\mathrm{PtMe}_{3}\right)_{2}\left(1-\mathrm{MeSCy}\left(1-\mathrm{MeSCy}_{-\mathrm{H}}\right)\right]^{+}\right.$at $\mathrm{m} / z=761$ (Fig. 4). The isotopic pattern has been found to be characteristic for a monocation containing two platinum atoms [natural isotopic composition: ${ }^{190} \mathrm{Pt}(0.01 \%)$, ${ }^{192} \mathrm{Pt}(0.79 \%),{ }^{194} \mathrm{Pt}(32.9 \%),{ }^{195} \mathrm{Pt}(33.8 \%),{ }^{196} \mathrm{Pt}$ $(25.3 \%)$ and $\left.{ }^{198} \mathrm{Pt}(7.2 \%)\right]$ in good agreement with calculated data. Furthermore, at $\mathrm{m} / z=381$ the monocation $\left[\mathrm{PtMe}_{3}(1-\mathrm{MeSCy})\right]^{+}$has been found. Collisioninduced dissociation (CID) experiments have shown that this peak is also formed by fragmentation of the isolated parent ion $\left[\left(\mathrm{PtMe}_{3}\right)_{2}(1-\mathrm{MeSCy})(1-\right.$ $\left.\left.\mathrm{MeSCy}_{-\mathrm{H}}\right)\right]^{+}$.

\section{Crystal structure of $\left[\left(\mathrm{PtMe}_{3}\right)_{2}(\mu-1-\mathrm{MeSCy}\right.$ -} $\left.\left.1 \kappa N^{3}, 1: 2 \kappa^{2} S\right)_{2}\right]\left[B F_{4}\right]_{2}\left(3 \cdot 1.5 C_{6} H_{6}\right)$

Colorless crystals of $\mathbf{3} \cdot 1.5 \mathrm{C}_{6} \mathrm{H}_{6}$ were obtained from acetone solutions layered with benzene and ether. The complex crystallizes as the racemate in the space group $P 2_{1} / c$. The crystals consist of the dinuclear cation $\left[\left(\mathrm{PtMe}_{3}\right)_{2}\left(\mu-1-\mathrm{MeSCy}-1 \kappa N^{3}, 1: 2 \kappa^{2} S\right)_{2}\right]^{2+}$, two $\left[\mathrm{BF}_{4}\right]^{-}$anions and one and a half benzene solvate molecules. The molecular structure of the cation of
Table 4. Selected bond lengths and angles of $\left[\left(\mathrm{PtMe}_{3}\right)_{2}(\mu-1-\right.$ MeSCy- $\left.\left.1 \kappa N^{3}, 1: 2 \kappa^{2} S\right)_{2}\right]\left(3 \cdot 1.5 \mathrm{C}_{6} \mathrm{H}_{6}\right)$ (distances in $\AA$, angles in deg).

\begin{tabular}{lrlrll}
\hline Pt1-C1 & $2.057(6)$ & Pt1-S1 & $2.551(2)$ & Pt2-S1 & $2.525(2)$ \\
Pt1-C3 & $2.055(8)$ & Pt1-S2 & $2.501(2)$ & Pt2-S2 & $2.542(2)$ \\
Pt2-C4 & $2.062(8)$ & Pt1-N4 & $2.257(5)$ & S1-C7 & $1.737(7)$ \\
Pt2-C5 & $2.047(6)$ & Pt2-N1 & $2.243(5)$ & S2-C12 & $1.726(7)$ \\
C1-Pt1-C2 & $87.7(4)$ & S1-C7-N1 & $114.2(5)$ & S2-Pt1-N4 & $66.0(1)$ \\
C3-Pt1-N4 & $166.7(3)$ & C4-Pt2-C5 & $87.7(3)$ & Pt1-S1-Pt2 & $92.56(6)$ \\
S1-Pt2-N1 & $65.4(1)$ & C6-Pt2-N1 & $166.8(3)$ & Pt1-S2-Pt2 & $93.34(6)$ \\
\hline
\end{tabular}

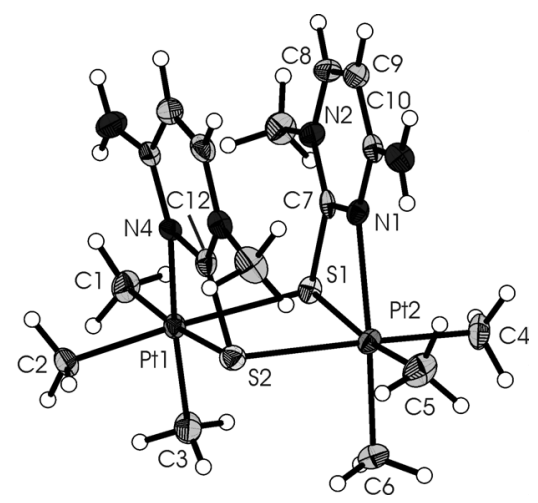

Fig. 5. Molecular structure of the cation of one enantiomer in crystals of $\left[\left(\mathrm{PtMe}_{3}\right)_{2}\left(\mu-1-\mathrm{MeSCy}-1 \kappa N^{3}, 1: 2 \kappa^{2} S\right)_{2}\right]\left[\mathrm{BF}_{4}\right]_{2}$ $\left(3 \cdot 1.5 \mathrm{C}_{6} \mathrm{H}_{6}\right)$. The displacement ellipsoids are drawn at the $30 \%$ probability level.

one enantiomer is shown in Fig. 5. Selected bond lengths and angles are given in Table 4. The primary donor sets of the octahedrally coordinated platinum atoms $\left[\mathrm{PtC}_{3} \mathrm{NS}_{2}\right]$ are built up of three methyl ligands in facial arrangement and two $\mu$-1-methyl-2thiocytosine- $1 \kappa N^{3}, 1: 2 \kappa^{2} S$ ligands. The central $\left[\mathrm{Pt}_{2}(\mu\right.$ -

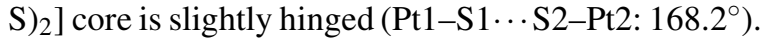
The two 1-methyl-2-thiocytosine ligands are arranged 
face-to-face, with the dinuclear molecule exhibiting $C_{2}$ symmetry in rough approximation. The distance between the heterocyclic ligands (3.4 $\AA$ ) as well as the angle between the centroid-centroid vector and the ring normal $\left(10.4^{\circ}\right)$ indicate stabilization through $\pi$ - $\pi$ stacking [19]. The chelating coordination of the 1-methyl-2-thiocytosine ligands leads to the formation of strained four-membered rings (S2Pt1-N4 66.0(1) ${ }^{\circ}$; S1-Pt2-N1 65.4(1) $)^{\circ}$, giving rise to greater deviations from the ideal octahedral coordination of the platinum atom. Moreover, the coordination of the sulfur atom to the platinum atom leads to a slight elongation of the S1-C7 and S2-C12 bonds (1.737(7)/1.726(7) ^) compared to the respective bond lengths in $1(1.702(3) / 1.692(3) \AA)$. In accordance with the high trans influence of the methyl ligands [25] the bridging Pt-S bonds (2.501(2)-2.551(2) A) are rather long (median: $2.490 \AA$, lower/upper quartile: $2.477 / 2.513 \AA$, for 41 observations [17]) but comparable to those in other dinuclear sulfur-bridged platinum(IV) complexes with trans methyl ligands (2.465(2)-2.551(1) ^) [26].

Inspection of the packing motif in crystals of $\mathbf{3} \cdot 1.5$ $\mathrm{C}_{6} \mathrm{H}_{6}$ reveals $\pi-\pi$ interactions between the heterocyclic ring $\mathrm{N} 1, \mathrm{~N} 2, \mathrm{C} 7-\mathrm{C} 10$ and one benzene ring (centroid-centroid distance: $3.6 \AA$; angle between the centroid-centroid vectors and the ring normals: $23.4^{\circ}$ ). Furthermore, there are cation-anion interactions formed through $\mathrm{N}-\mathrm{H} \cdots \mathrm{F}$ and $\mathrm{C}-\mathrm{H} \cdots \mathrm{F}$ hydrogen bonds, involving the fluorine atoms of the $\left[\mathrm{BF}_{4}\right]^{-}$anions.

\section{Conclusions}

The possible tautomers of 1-methyl-2-thiocytosine, namely the thione-amino form (1a) as the most stable tautomer both in the gas and aqueous phase, the iminothiol tautomer (1b) and the imino-thione tautomer (1c) are shown in Scheme 2 [8]. In the present investigations it has been demonstrated that the tautomer 1a is also present in crystals of $\mathbf{1}$. The same holds for the molecular structures of thiocytidine [27] and 2thiocytosine [10], as shown by previous X-ray diffraction analyses.

The hydrogen bonding pattern in crystals of 1MeSCy (1) was found to be very similar to that in 1-methylcytosine crystals (1-MeCy, see Formula $\mathbf{I}$ in Scheme 2) $[13,14]$. The oxygen analog also forms centrosymmetric dimers through two identical N4$\mathrm{H} \cdots \mathrm{N} 3^{\prime}$ hydrogen bonds. These dimeric units are

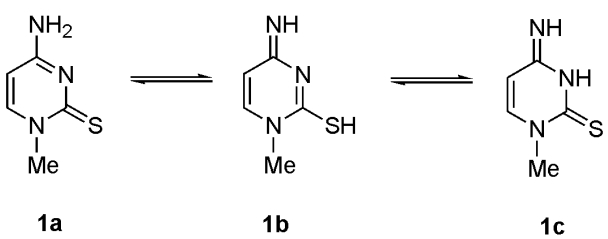

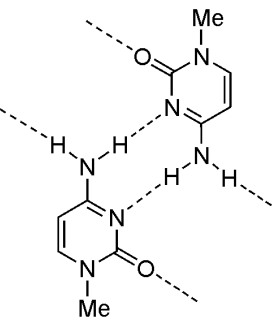

I

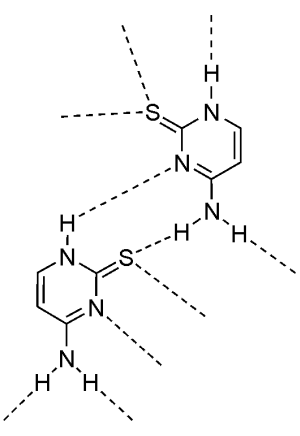

II
Scheme 2.

connected through $\mathrm{N} 4-\mathrm{H}$... O hydrogen bonds forming ribbons. In crystals of the non-methylated 2thiocytosine a more complex hydrogen bonding pattern was observed (see Formula II in Scheme 2), which is completely different from that in 1-MeSCy (1). The central unit is also a dimer, but the two halves are linked unsymmetrically through $\mathrm{N} 1-\mathrm{H} \cdots \mathrm{N} 3^{\prime}$ and $\mathrm{N} 4{ }^{\prime}-\mathrm{H} \cdots \mathrm{S}$ hydrogen bonds. Further weaker $\mathrm{N}-\mathrm{H} \cdots \mathrm{N}$ and $\mathrm{N}-\mathrm{H} \cdots \mathrm{S}$ hydrogen bonds are connecting the dimers yielding ribbons [10].

Apart from the $\left[\mathrm{PtMe}_{3}(\mathrm{bpy})(1-\mathrm{MeSCy}-\kappa S)\right]\left[\mathrm{BF}_{4}\right]$ complex reported by us [12], the new compound $\left[\left(\mathrm{PtMe}_{3}\right)_{2}\left(\mu-1-\mathrm{MeSCy}-1 \kappa N^{3}, 1: 2 \kappa^{2} S\right)_{2}\right]\left[\mathrm{BF}_{4}\right]_{2} \quad(3)$ is the first transition metal complex containing 1-methyl2-thiocytosine ligands. By contrast, a large number of transition metal complexes with the oxygen ana$\log$ 1-methylcytosine (1-MeCy) are known [28]. In its platinum(II) complexes predominantly N3 coordination is observed [29], and frequently an additional coordination of $\mathrm{N} 4$ of the monodeprotonated 1-methylcytosinato ligands to another Pt or Pd center gives rise to the formation of complexes having bridging $\mu-1-\mathrm{MeCy}-1 \kappa N^{3}, 2 \kappa N^{4}$ ligands [30]. On the other hand, a chelating coordination through $\mathrm{N} 3$ and $\mathrm{O}$ $\left(1-\mathrm{MeCy}-\kappa N^{3}, \kappa O\right.$ ligands) in 1-methylcytosine metal complexes analogous to that in complex $\mathbf{3}$ is rare [31].

The heterocyclic rings in $\mathbf{3}$ have been found to be in a face-to-face arrangement, as in the neutral dinuclear complexes of the type $\left[\left(\mathrm{PtMe}_{3}\right)_{2}\left(\mu-\mathrm{S}^{\wedge} \mathrm{N}-\right.\right.$ 
$\left.1 \kappa N, 1: 2 \kappa^{2} S\right)_{2}$ ] [26], with the geometrical parameters (Pt-S and $\mathrm{C}-\mathrm{S}$ bond lengths, $\mathrm{Pt} 1-\mathrm{S} 1 \cdots \mathrm{S} 2-\mathrm{Pt} 2$ dihedral angle, $\pi-\pi$ stacking) in the same order of magnitude. Thus, the synthesis of $\left[\left(\mathrm{PtMe}_{3}\right)_{2}(\mu-1-\mathrm{MeSCy}-\right.$ $\left.\left.1 \kappa N^{3}, 1: 2 \kappa^{2} S\right)_{2}\right]\left[\mathrm{BF}_{4}\right]_{2}(3)$ has provided another example of the versatile coordination modes of thionucleobase models.

\section{Experimental Section}

General considerations

The synthesis of $\left[\left(\mathrm{PtMe}_{3}\right)_{2}\left(\mu-1-\mathrm{MeSCy}-1 \kappa N^{3}\right.\right.$,$\left.\left.1: 2 \kappa^{2} S\right)_{2}\right]\left[\mathrm{BF}_{4}\right]_{2}$ (3) was performed under argon using standard Schlenk techniques. Acetone was dried over phosphorus pentoxide. Benzene and diethyl ether were dried over Na benzophenone. All solvents were distilled prior to use. NMR spectra were obtained with Varian UNITY 500 and Gemini 2000 spectrometers using solvent signals $\left({ }^{1} \mathrm{H}\right.$ and ${ }^{13} \mathrm{C}-\mathrm{NMR}$ spectroscopy) as internal references and $\mathrm{Na}_{2}\left[\mathrm{PtCl}_{6}\right]\left(\delta\left({ }^{195} \mathrm{Pt}\right)=0 \mathrm{ppm}\right)$ as external reference. IR spectra were recorded on a Galaxy Mattson FT IR spectrometer, using $\mathrm{KBr}$ pellets. Microanalyses were performed by the University of Halle microanalytical laboratory using a CHNS-932 (LECO) instrument. The ESI mass spectrum was obtained on a Finnigan LCQ spectrometer (Thermo Electron Corp.) using a $10^{-5} \mathrm{M}$ solution of the complex in acetone under the following conditions: flow $8 \mu \mathrm{L} / \mathrm{min}$, positive ion polarity mode, ESI spray voltage $4.1 \mathrm{kV}$; capillary temperature $200{ }^{\circ} \mathrm{C}$; capillary voltage $34 \mathrm{~V}$; tube lens offset $10 \mathrm{~V}$; sheath gas $\mathrm{N}_{2}$; damping gas He. The CID experiments were carried out in the mass analyzer region with use of $\mathrm{He}$ as the collision gas and by applying a resonance excitation $\mathrm{RF}$ voltage (varying from 0 to $5 \mathrm{~V}$, peak-to-peak). The masses, charge states and isotopic envelopes of the parent and fragment ions (CID) were established by applying the zoom-scan mode (high resolution $<0.2,10$ a.m. u. width). 1-Methyl-2-thiocytosine (1) [32] and [( $\left.\left.\mathrm{PtMe}_{3} \mathrm{I}\right)_{4}\right]$ [33] were prepared according to the literature. All other chemicals were purchased from commercial sources.

Spectroscopic characterization of 1-methyl-2-thiocytosine (1) and synthesis of [(PtMe $)_{2}(\mu-1-M e S C y-$ $\left.\left.1 \kappa N^{3}, 1: 2 \kappa^{2} S\right)_{2}\right]\left[B F_{4}\right]_{2}(3)$

\section{1-Methyl-2-thiocytosine (1)}

Yield: $1.2 \mathrm{~g}(70 \%) .-{ }^{1} \mathrm{H}-\mathrm{NMR}\left(400 \mathrm{MHz}, \mathrm{CD}_{3} \mathrm{OD}\right)$ : $\delta=7.73\left(\mathrm{~d},{ }^{3} J_{\mathrm{H}, \mathrm{H}}=7.3 \mathrm{~Hz}, 1 \mathrm{H}, \mathrm{H} 6\right), 6.09\left(\mathrm{~d},{ }^{3} J_{\mathrm{H}, \mathrm{H}}=\right.$ $7.3 \mathrm{~Hz}, 1 \mathrm{H}, \mathrm{H} 5), 3.72$ (s, 3H, NCH$)_{3}$. $-{ }^{1} \mathrm{H}-\mathrm{NMR}(400 \mathrm{MHz}$, [D ${ }_{6}$ ]DMSO): $\delta=7.81\left(\mathrm{~d},{ }^{3} J_{\mathrm{H}, \mathrm{H}}=7.3 \mathrm{~Hz}, 1 \mathrm{H}, \mathrm{H} 6\right), 7.48$ (s, br, $\left.1 \mathrm{H}, \mathrm{NH}_{2}\right), 7.41\left(\mathrm{~s}, \mathrm{br}, 1 \mathrm{H}, \mathrm{N} H_{2}\right), 5.98\left(\mathrm{~d},{ }^{3} J_{\mathrm{H}, \mathrm{H}}=\right.$ $7.3 \mathrm{~Hz}, 1 \mathrm{H}, \mathrm{H} 5), 3.59$ (s, 3H, NCH ). $-{ }^{13} \mathrm{C}-\mathrm{NMR}(100 \mathrm{MHz}$, [D $\mathrm{D}_{6}$ DMSO): $\delta=180.6(\mathrm{C} 2), 160.5$ (C4), 146.8 (C6), 97.0
Table 5. Crystal data, data collection and refinement parameters of $1-\mathrm{MeSCy}(\mathbf{1})$ and $\left[\left(\mathrm{PtMe}_{3}\right)_{2}(\mu-1-\mathrm{MeSCy}-\right.$ $\left.\left.1 \kappa N^{3}, 1: 2 \kappa^{2} S\right)_{2}\right]\left[\mathrm{BF}_{4}\right]_{2}\left(3 \cdot 1.5 \mathrm{C}_{6} \mathrm{H}_{6}\right)$.

\begin{tabular}{|c|c|c|}
\hline & 1 & $\mathbf{3} \cdot 1.5 \mathrm{C}_{6} \mathrm{H}_{6}$ \\
\hline Empirical formula & $\mathrm{C}_{5} \mathrm{H}_{7} \mathrm{~N}_{3} \mathrm{~S}$ & $\mathrm{C}_{25} \mathrm{H}_{41} \mathrm{~B}_{2} \mathrm{~F}_{8} \mathrm{~N}_{6} \mathrm{Pt}_{2} \mathrm{~S}_{2}$ \\
\hline Formula weight & 141.20 & 1053.56 \\
\hline Crystal system/ & monoclinic & monoclinic \\
\hline Space group & $P 2_{1} / n$ & $P 2_{1} / c$ \\
\hline$Z$ & 8 & 4 \\
\hline$a, \AA$ & $5.9919(8)$ & $10.2340(5)$ \\
\hline$b, \AA$ & $19.343(3)$ & $35.854(2)$ \\
\hline$c, \AA$ & $11.293(7)$ & $9.9832(5)$ \\
\hline$\beta$, deg & $99.14(1)$ & $107.701(6)$ \\
\hline$V, \AA^{3}$ & $1292.3(8)$ & $3489.7(3)$ \\
\hline$\rho, \mathrm{g} \mathrm{cm}^{-3}$ & 1.44 & 2.01 \\
\hline$\mu\left(\mathrm{Mo} K_{\alpha}\right), \mathrm{mm}^{-1}$ & 0.4 & 8.2 \\
\hline$F(000), \mathrm{e}$ & 592 & 2012 \\
\hline Scan range, deg & $2.11 \leq \theta \leq 25.03$ & $2.09 \leq \theta \leq 26.02$ \\
\hline $\begin{array}{l}\text { Reciprocal lattice } \\
\text { segment } h k l\end{array}$ & $\pm 7,+23,-8 \rightarrow 13$ & $\pm 12, \pm 44,-11 \rightarrow 12$ \\
\hline Refl. collected & 2473 & 18975 \\
\hline Refl. independent / $R_{\text {int }}$ & $2252 / 0.0580$ & $6517 / 0.0675$ \\
\hline Data / parameters & $2252 / 220$ & $6517 / 413$ \\
\hline$R_{1} / w R_{2}[I \geq 2 \sigma(I)]$ & $0.0407 / 0.0943$ & $0.0338 / 0.0670$ \\
\hline$R_{1} / w R_{2}$ (all data) & $0.0602 / 0.1080$ & $0.0581 / 0.0732$ \\
\hline Goodness-of-fit on $F^{2}$ & 1.094 & 0.934 \\
\hline $\begin{array}{l}\text { Largest diff. peak / } \\
\text { hole, e } \AA^{-3}\end{array}$ & $0.20 /-0.18$ & $1.09 /-0.78$ \\
\hline
\end{tabular}

(C5), 43.3 (C1). - $\mathrm{C}_{5} \mathrm{H}_{7} \mathrm{~N}_{3} \mathrm{~S}$ (141.04): calcd. C 42.54, H 5.00, N 29.79; found C 42.55, H 5.29, N 29.31.

$\left[\left(\mathrm{PtMe}_{3}\right)_{2}\left(\mu-1-\mathrm{MeSCy}-1 \kappa N^{3}, 1: 2 \kappa^{2} S\right)_{2}\right]\left[\mathrm{BF}_{4}\right]_{2}(3)$

A suspension of $\left[\left(\mathrm{PtMe}_{3} \mathrm{I}\right)_{4}\right](50.0 \mathrm{mg}, 0.04 \mathrm{mmol})$ and $\mathrm{Ag}\left[\mathrm{BF}_{4}\right](27.0 \mathrm{mg}, 0.14 \mathrm{mmol})$ in acetone $(10 \mathrm{~mL})$ was stirred for $30 \mathrm{~min}$ in the absence of light. Silver iodide was removed by filtration, and the clear, colorless filtrate was added directly to 1-methyl-2-thiocytosine (19.3 mg, $0.14 \mathrm{~mol}$ ). After stirring for $2 \mathrm{~h}$ the volume was reduced in vacuo to $1 \mathrm{~mL}$, and ether $(3 \mathrm{~mL})$ was added. The colorless precipitate was isolated, washed with pentane $(2 \times 2 \mathrm{~mL})$ and dried in vacuo. Yield: $72 \mathrm{mg}$ (56\%). IR (KBr): $v=3454 \mathrm{~m}, 3352 \mathrm{~m}, 3111 \mathrm{w}$, 2961 w, 2899 m, 1792 w, 1650 s, 1537 m, 1506 s, 1400 m, $1368 \mathrm{~m}, 1215 \mathrm{~m}, 1081 \mathrm{~s}, 821 \mathrm{w} \mathrm{cm}^{-1}$. - ${ }^{1} \mathrm{H}-\mathrm{NMR}(500$ $\mathrm{MHz}, \mathrm{CD}_{3} \mathrm{OD}$, r.t.): $\delta=7.98\left(\mathrm{~d},{ }^{3} J_{\mathrm{H}, \mathrm{H}}=7.5 \mathrm{~Hz}, 2 \mathrm{H}\right.$, $\left.H 6 / H 6^{\prime}\right), 6.53\left(\mathrm{~d},{ }^{3} J_{\mathrm{H}, \mathrm{H}}=7.5 \mathrm{~Hz},{ }^{4} J_{\mathrm{Pt}, \mathrm{H}}=11.6 \mathrm{~Hz}, 2 \mathrm{H}\right.$, $\left.H 5 / H 5^{\prime}\right), 3.64\left(\mathrm{~s}, 6 \mathrm{H}, \mathrm{NCH}_{3}, \mathrm{NCH}_{3}{ }^{\prime}\right), 1.22\left(\mathrm{~s}+\mathrm{d},{ }^{2} J_{\mathrm{Pt}, \mathrm{H}}=\right.$ $\left.75.5 \mathrm{~Hz}, 18 \mathrm{H}, \mathrm{Pt}\left(\mathrm{CH}_{3}\right)_{3}\right) .-{ }^{1} \mathrm{H}-\mathrm{NMR}\left(500 \mathrm{MHz}, \mathrm{CD}_{3} \mathrm{OD}\right.$, $\left.-50{ }^{\circ} \mathrm{C}\right): \delta=8.05\left(\mathrm{~d},{ }^{3} J_{\mathrm{H}, \mathrm{H}}=7.5 \mathrm{~Hz}, 2 \mathrm{H}, H 6 / H 6^{\prime}\right), 6.53$ $\left(\mathrm{d},{ }^{3} J_{\mathrm{H}, \mathrm{H}}=7.5 \mathrm{~Hz}, 2 \mathrm{H}, H 5 / H 5^{\prime}\right), 3.63\left(\mathrm{~s}, 6 \mathrm{H}, \mathrm{NCH}_{3}\right.$, $\left.\mathrm{NCH}_{3}^{\prime}\right), 1.194\left(\mathrm{~s}+\mathrm{d},{ }^{2} J_{\mathrm{Pt}, \mathrm{H}}=81.5 \mathrm{~Hz}, 6 \mathrm{H}, \mathrm{PtCH}_{3}\right), 1.189$ $\left(\mathrm{s}+\mathrm{d},{ }^{2} J_{\mathrm{Pt}, \mathrm{H}}=74.7 \mathrm{~Hz}, 6 \mathrm{H}, \mathrm{PtCH}_{3}\right) .-{ }^{13} \mathrm{C}-\mathrm{NMR}(125 \mathrm{MHz}$, $\left.\mathrm{CD}_{3} \mathrm{OD}\right): \delta=184.4(C 2), 160.4(C 4), 147.8(C 6), 101.8$ $(C 5), 40.7\left(\mathrm{NCH}_{3}\right),-7.3\left(\mathrm{~s}+\mathrm{d}, \mathrm{br}, \mathrm{Pt}\left(\mathrm{CH}_{3}\right)_{3}\right) . \quad-{ }^{195} \mathrm{Pt}-$ NMR (107 MHz, CD 3 OD): $\delta=-2318.4$. - MS ((+)-ESI): $m / z(\%)=761(62)\left[\left(\mathrm{PtMe}_{3}\right)_{2}(1-\mathrm{MeSCy})\left(1-\mathrm{MeSCy}_{-\mathrm{H}}\right)\right]^{+}$, 
381 (100) $\left[\left(\mathrm{PtMe}_{3}\right)(1-\mathrm{MeSCy})\right]^{+} .-\mathrm{C}_{16} \mathrm{H}_{34} \mathrm{~B}_{2} \mathrm{~F}_{8} \mathrm{~N}_{6} \mathrm{~S}_{2} \mathrm{Pt}_{2}$ (938.16): calcd. C 20.47, H 3.65, N 8.96; found C 20.13, H 4.13, N 8.74.

\section{$X$-Ray crystallography}

Single crystals of $\mathbf{1}$ and $\mathbf{3} \cdot 1.5 \mathrm{C}_{6} \mathrm{H}_{6}$, suitable for X-ray diffraction measurements, were obtained by recrystallization from ethanol (1) and acetone/benzene $\left(3 \cdot 1.5 \mathrm{C}_{6} \mathrm{H}_{6}\right)$. Intensity data were collected on a STADI (1) and a Stoe IPDS diffractometer $\left(3 \cdot 1.5 \mathrm{C}_{6} \mathrm{H}_{6}\right)$ with $\operatorname{Mo} K_{\alpha}$ radiation $(\lambda=$ $0.71073 \AA$, graphite monochromator) at 293(2) K (1) and $220(2) \mathrm{K}\left(3 \cdot 1.5 \mathrm{C}_{6} \mathrm{H}_{6}\right)$. A summary of the crystallographic data, the data collection parameters and the refinement parameters is given in Table 5. A numerical absorption correction was applied for $3 \cdot 1.5 \mathrm{C}_{6} \mathrm{H}_{6}\left(T_{\min } / T_{\max }=0.24 /\right.$ 0.58). The structures were solved by Direct Methods with SHELXS-97 [34] and refined using full-matrix least-squares routines against $F^{2}$ with SHELXL-97 [34]. Non-hydrogen atoms were refined with anisotropic displacement parameters. Hydrogen atoms in 1-MeSCy (1) were found in the difference Fourier map and refined freely, whereas the hydrogen atoms in $3 \cdot 1.5 \mathrm{C}_{6} \mathrm{H}_{6}$ were positioned geometrically and refined with isotropic displacement parameters according to the "riding model".

CCDC 761534 and CCDC 761535 contain the supplementary crystallographic data for compounds $\mathbf{1}$ and $\mathbf{3} \cdot 1.5$
$\mathrm{C}_{6} \mathrm{H}_{6}$. These data can be obtained free of charge via www.ccdc.cam.ac.uk/data_request/cif.

\section{Quantum-chemical calculations}

All DFT calculations were carried out by the GAUSSIAN03 program package [35] using the hybrid functional B3LYP [36] and the basis sets $6-31++G(d, p)$ as implemented in the GAUSSIAN program. All systems were fully optimized. For the monomeric molecule no symmetry restrictions were applied, whereas the dimeric and tetrameric molecules were calculated in $C_{\mathrm{i}}$ symmetry. The resulting geometries were characterized as equilibrium structures by the analysis of the force constants of the normal vibrations. Basis set superposition errors (BSSE) were estimated with counterpoise-type calculations [37].

\section{Supplementary Information}

Tables of Cartesian coordinates of atom positions calculated for the equilibrium structures of the monomer $\mathbf{1 m}$, the hydrogen-bonded dimer $\mathbf{1 d}$ and tetramer $\mathbf{1 t}$ (available online only).

\section{Acknowledgement}

Gifts of chemicals by Merck (Darmstadt) are gratefully acknowledged.
[1] J. A. Carbon, L. Hung, D. S. Jones, Proc. Natl. Acad. Sci. U. S. A. 1965, 53, 979.

[2] M. N. Lipsett, J. Biol. Chem. 1965, 240, 3975.

[3] J. Carbon, H. David, M. H. Studier, Science 1968, 161, 1146.

[4] D. H. Gauss, M. Sprinzl, Nucleic Acids Res. 1983, 11, r1.

[5] Y. Yamada, M. Saneyoshi, S. Nishimura, H. Ishikura FEBS Lett. 1970, 7, 207.

[6] J. G. Contreras, J. B. Alderete, J. Phys. Org. Chem. 1995, 8, 395.

[7] Y. Podolyan, L. Gorb, A. Blue, J. Leszczynski, J. Mol. Struct. (Theochem.) 2001, 549, 101.

[8] P. Ü. Civcir, J. Phys. Org. Chem. 2001, 14, 171.

[9] H. Rostkowska, M. J. Nowak, L. Lapinski, M. Bretner, T. Kulikowski. A. Lés, L. Adamowicz, Spectrochim. Acta Part A 1993, 49, 551.

[10] S. Furberg, L. H. Jensen, Acta Crystallogr. 1970, B26, 1260.

[11] a) B. T. Khan, S. M. Zakeeruddin, Trans. Met. Chem. 1991, 16, 119; b) B.T. Khan, T. K. Annapoorna, S. Shamsuddin, K. Najmuddin, Polyhedron 1992, 11, 2109; c) J. Jolley, W. I. Cross, R. G. Pritchard, C. A. McAuliffe, K. B. Nolan, Inorg. Chim. Acta 2001, 315, 36; d) T. E. Chávez-Gil, E. Meléndez, In- org. Chim. Acta 2004, 357, 1092; e) E. Meléndez, M. Marrero, C. Rivera, E. Hernandez, A. Segal, Inorg. Chim. Acta 2000, 298, 178; f) J.D. E. T. Wilton-Ely, M. Wang, D. M. Benoit, D. A. Tocher, Eur. J. Inorg. Chem. 2006, 3068; g) C.-L. Ma, Y. Shi, Q.-F. Zhang, Q. Jiang, Polyhedron 2005, 24, 1109.

[12] a) C. Vetter, C. Wagner, G. N. Kaluđerović, R. Paschke, D. Steinborn, Inorg. Chim. Acta 2009, 362, 189; b) M. W. Whitehouse, P.D. Cookson, G. Siasios, E. R. T. Tiekink, Met.-Based Drugs 1998， 5, 245; c) E. R. T. Tiekink, P. D. Cookson, B. M. Linahan, L. K. Webster, Met.-Based Drugs 1994, 1, 299; d) L. K. Webster, S. Rainone, E. Horn, E. R. T. Tiekink, Met.-Based Drugs 1996, 3, 63.

[13] F. S. Mathews, A. Rich, Nature 1964, 201, 179.

[14] M. Rossi, T. J. Kistenmacher, Acta Crystallogr. 1977, B33, 3962.

[15] S. C. Nyburg, C. H. Faerman, L. Prasad, Acta Crystallogr. 1987, B43, 106.

[16] S. C. Nyburg, C. H. Faerman, Acta Crystallogr. 1985, B41, 274.

[17] Cambridge Structural Database (CSD) Version 5.30 2008, University Chemical Laboratory, Cambridge (England). 
[18] G. A. Jeffrey, W. Saenger, Hydrogen Bonding in Biological Structures, Springer Verlag, Berlin, 1994, pp. 132.

[19] C. Janiak, J. Chem. Soc., Dalton Trans. 2000, 3885.

[20] W. Koch, M. C. Holthausen, A Chemist's Guide to Density Functional Theory, Wiley-VCH, Weinheim 2000, p. 213.

[21] M. W. Feyereisen, D. Feller, D. A. Dixon, J. Phys. Chem. 1996, 100, 2993.

[22] a) J. Emsley, Chem. Soc. Rev. 1980, 9, 91; b) G. A. Jeffrey, An Introduction to Hydrogen Bonding, Oxford University Press, Oxford, 1997.

[23] H. Junicke, C. Bruhn, D. Ströhl, R. Kluge, D. Steinborn, Inorg. Chem. 1998, 37, 4603.

[24] F. Pichierri, D. Holthenrich, E. Zangrando, B. Lippert, L. Randaccio, J. Biol. Inorg. Chem. 1996, 1, 439.

[25] a) T. G. Appleton, H. C. Clark, L.E. Manzer, Coord. Chem. Rev. 1973, 10, 335; b) C. Vetter, C. Wagner, J. Schmidt, D. Steinborn, Inorg. Chim. Acta 2006, 359, 4326.

[26] C. Vetter, G. N. Kaluđerović, R. Paschke, S. GómezRuiz, D. Steinborn, Polyhedron 2009, 28, 3699.

[27] G. H.-Y. Lin, M. Sundaralingam, S. K. Arora, J. Am. Chem. Soc. 1971, 93, 1235.

[28] B. Lippert, Coord. Chem. Rev. 2000, 200-202, 487.

[29] a) W.-Z. Shen, G. Trötscher-Kaus, B. Lippert, Dalton Trans. 2009, 8203; b) K. Butsch, S. Elmas, N. S. Gupta, R. Gust, F. Heinrich, A. Klein, Y. v. Mering, M. Neugebauer, I. Ott, M. Schäfer, H. Scherer, T. Schurr, Organometallics 2009, 28, 3906; c) B. Longato, D. Montagner, E. Zangrando, Dalton Trans. 2009, 2400; d) P. J. Sanz Miguel, P. Lax, B. Lippert, J. Inorg. Biochem. 2006, 100, 980.

[30] a) G. Kampf, P. J. Sanz Miguel, M. M. Cerdà, M. Willermann, B. Lippert, A. Schneider, Chem. Eur. J. 2008, 14, 6882; b) G. Kampf, M. Willermann, E. Zangrando, L. Randaccio, B. Lippert, Chem. Commun. 2001, 747; c) F. Pichierri, E. Chiarparin, E. Zangrando, L. Randaccio, D. Holthenrich, B. Lippert, Inorg. Chim. Acta 1997, 264, 109; d) T. Wienkoetter, M. Sabat, G. Fusch, B. Lippert, Inorg. Chem. 1995, $34,1022$.
[31] a) T. F. Mastropietro, D. Armentano, N. Marino, G. De Munno, J. Anastassopoulou, T. Theophanides, Cryst. Growth Des. 2007, 7, 609; b) G. Valle, R. Ettorre, V. Peruzzo, Acta Crystallogr. 1996, C52, 626.

[32] D. J. Brown, B. T. England, J. Chem. Soc. C 1971, 2507.

[33] a) W. J. Pope, S. J. Peachey, Proc. Chem. Soc. 1907, 23, 86; b) J. C. Baldwin, W. C. Kaska, Inorg. Chem. 1975, 14, 2020.

[34] G. M. Sheldrick, SHElXs/L-97, Programs for Crystal Structure Determination, University of Göttingen, Göttingen (Germany) 1997. See also: G. M. Sheldrick, Acta Crystallogr. 1990, A46, 467; ibid. 2008, A64, 112.

[35] M. J. Frisch, G. W. Trucks, H. B. Schlegel, G. E. Scuseria, M. A. Robb, J. R. Cheeseman, J. A. Montgomery, Jr., T. Vreven, K. N. Kudin, J. C. Burant, J. M. Millam, S. S. Iyengar, J. Tomasi, V. Barone, B. Mennucci, M. Cossi, G. Scalmani, N. Rega, G. A. Petersson, H. Nakatsuji, M. Hada, M. Ehara, K. Toyota, R. Fukuda, J. Hasegawa, M. Ishida, T. Nakajima, Y. Honda, O. Kitao, H. Nakai, M. Klene, X. Li, J.E. Knox, H.P. Hratchian, J.B. Cross, V. Bakken, C. Adamo, J. Jaramillo, R. Gomperts, R. E. Stratmann, O. Yazyev, A. J. Austin, R. Cammi, C. Pomelli, J. W. Ochterski, P. Y. Ayala, K. Morokuma, G. A. Voth, P. Salvador, J. J. Dannenberg, V. G. Zakrzewski, S. Dapprich, A.D. Daniels, M. C. Strain, O. Farkas, D. K. Malick, A.D. Rabuck, K. Raghavachari, J. B. Foresman, J. V. Ortiz, Q. Cui, A. G. Baboul, S. Clifford, J. Cioslowski, B. B. Stefanov, G. Liu, A. Liashenko, P. Piskorz, I. Komaromi, R. L. Martin, D. J. Fox, T. Keith, M. A. Al-Laham, C. Y. Peng, A. Nanayakkara, M. Challacombe, P. M. W. Gill, B. Johnson, W. Chen, M. W. Wong, C. Gonzalez, J. A. Pople, GAUSSIAN 03 (revision C.02), Gaussian, Inc., Wallingford, CT (USA) 2004.

[36] a) A. D. Becke, Phys. Rev. A 1988, 38, 3098; b) A. D. Becke, J. Chem. Phys. 1993, 98, 5648; c) C. Lee, W. Yang, R. G. Parr, Phys. Rev. B 1988, 37, 785; d) P. J. Stephens, F. J. Devlin, C. F. Chabalowski, M. J. Frisch, J. Phys. Chem. 1994, 98, 11623.

[37] S. F. Boys, F. Bernardi, Mol. Phys. 1970, 19, 553. 


\title{
Supplementary Material to
}

\section{Structural and Computational Studies of 1-Methyl-2-thiocytosine and its}

\author{
Coordination Mode in a Dinuclear Platinum(IV) Complex
}

\author{
$\left[\left(\mathrm{PtMe}_{3}\right)_{2}\left(\mu-1-\mathrm{MeSCy}-1 \kappa N^{3}, 1: 2 \kappa^{2} S\right)_{2}\right]\left[\mathrm{BF}_{4}\right]_{2}$
}

\author{
Cornelia Vetter, Christoph Wagner, Ralph Kluge, Dirk Steinborn* \\ ENERGIES AND CARTESIAN COORDINATES OF ATOM POSITIONS OF \\ CALCULATED MOLECULES
}

Calculation type: B3LYP/6-31++G**

1. 1-MeSCy (monomer) (1m)

File: MeSCy_03.out

$\mathrm{E}(\mathrm{RB}+\mathrm{HF}-\mathrm{LYP})$ :

-757.223281659 a.u.

Zero-point vibrational energy:

$77.68115 \mathrm{kcal} / \mathrm{mol}$

Sum of electronic and thermal free energies: $\quad-757.133187$ a.u.

$\begin{array}{lrrr}\mathrm{C} & -1.99341800 & 1.57516600 & 0.00151800 \\ \mathrm{~N} & -0.67316900 & 0.93742200 & -0.00023600 \\ \mathrm{C} & -0.57309500 & -0.47942100 & -0.00096400 \\ \mathrm{C} & 0.44747000 & 1.70766100 & 0.00054200 \\ \mathrm{~N} & 0.67171500 & -1.02061900 & 0.00027600 \\ \mathrm{~S} & -1.96100800 & -1.42240800 & 0.00075100 \\ \mathrm{C} & 1.69737700 & 1.16597000 & -0.00065500 \\ \mathrm{C} & 1.75694800 & -0.26462400 & -0.00175800 \\ \mathrm{~N} & 2.95751600 & -0.90448400 & -0.02657800 \\ \mathrm{H} & -2.55884400 & 1.26289500 & -0.87876400 \\ \mathrm{H} & -2.55514100 & 1.26641700 & 0.88550100 \\ \mathrm{H} & -1.85522500 & 2.65829600 & -0.00090800 \\ \mathrm{H} & 2.58000200 & 1.79331900 & -0.00662800 \\ \mathrm{H} & 0.28820200 & 2.78020700 & 0.00090400 \\ \mathrm{H} & 3.82054100 & -0.40737100 & 0.11871100 \\ \mathrm{H} & 2.95246400 & -1.90998100 & 0.06284400\end{array}$

2. (1-MeSCy) ${ }_{2}$ (dimer of AA' type) (1d)

File: MeSCy_01.out and MeSCy_01bsse.out

$\mathrm{E}(\mathrm{RB}+\mathrm{HF}-\mathrm{LYP})$ :

Zero-point vibrational energy:

Sum of electronic and thermal free energies:

Counterpoise corrected energy:

Counterpoise BSSE energy:
-1514.47877641 a.u.

$157.07258 \mathrm{kcal} / \mathrm{mol}$

-1514.277264 a.u.

-1514.477426867834 a.u.

0.001349544075 a.u. $(0.847 \mathrm{kcal} / \mathrm{mol})$ 


$\begin{array}{lrrc}\mathrm{C} & -5.55121800 & 0.07138700 & 0.20016500 \\ \mathrm{~N} & -4.19622000 & 0.04438600 & -0.35949100 \\ \mathrm{C} & -3.07586100 & 0.04490800 & 0.49901500 \\ \mathrm{C} & -4.02065800 & 0.01870700 & -1.71231500 \\ \mathrm{~N} & -1.84765200 & 0.01847300 & -0.06206300 \\ \mathrm{~S} & -3.28779600 & 0.07802200 & 2.17435400 \\ \mathrm{C} & -2.78739400 & -0.00724200 & -2.28377900 \\ \mathrm{C} & -1.66397500 & -0.00707700 & -1.39010400 \\ \mathrm{~N} & -0.40415800 & -0.03179200 & -1.84067400 \\ \mathrm{H} & -5.70874500 & -0.79911500 & 0.84026700 \\ \mathrm{H} & -5.68567700 & 0.96655000 & 0.81054600 \\ \mathrm{H} & -6.26589500 & 0.06671700 & -0.62500700 \\ \mathrm{H} & -2.66972300 & -0.02731900 & -3.35997600 \\ \mathrm{H} & -4.92713200 & 0.02026600 & -2.30720600 \\ \mathrm{H} & -0.19315700 & -0.05031300 & -2.82579600 \\ \mathrm{H} & 0.38449000 & -0.03451200 & -1.17551500 \\ \mathrm{~N} & 1.84765200 & -0.01847300 & 0.06206300 \\ \mathrm{C} & 3.07586100 & -0.04490800 & -0.49901500 \\ \mathrm{C} & 1.66397500 & 0.00707700 & 1.39010400 \\ \mathrm{~N} & 4.19622000 & -0.04438600 & 0.35949100 \\ \mathrm{~S} & 3.28779600 & -0.07802200 & -2.17435400 \\ \mathrm{C} & 2.78739400 & 0.00724200 & 2.28377900 \\ \mathrm{~N} & 0.40415800 & 0.03179200 & 1.84067400 \\ \mathrm{C} & 5.55121800 & -0.07138700 & -0.20016500 \\ \mathrm{C} & 4.02065800 & -0.01870700 & 1.71231500 \\ \mathrm{H} & 2.66972300 & 0.02731900 & 3.35997600 \\ \mathrm{H} & 0.19315700 & 0.05031300 & 2.82579600 \\ \mathrm{H} & -0.38449000 & 0.03451200 & 1.17551500 \\ \mathrm{H} & 5.70874500 & 0.79911500 & -0.84026700 \\ \mathrm{H} & 5.68567700 & -0.96655000 & -0.81054600 \\ \mathrm{H} & 6.26589500 & -0.06671700 & 0.62500700 \\ \mathrm{H} & 4.92713200 & -0.02026600 & 2.30720600 \\ & & & \\ & & & \\ & & & \end{array}$

\section{3. (1-MeSCy) ${ }_{4}$ (tetramer of BAA'B' type) (1t)}

File: MeSCY_04neurechner.log and MeSCY_04neurechner_bsse.out

$\mathrm{E}(\mathrm{RB}+\mathrm{HF}-\mathrm{LYP})=-3028.95995843$ a.u.

Zero-point vibrational energy:

Sum of electronic and thermal free energies:

Counterpoise corrected energy:

Counterpoise BSSE energy:
$315.38327 \mathrm{kcal} / \mathrm{mol}$ -3028.538912 a.u. -3028.956639011027 a.u. 0.003403365256 a.u. $(2.136 \mathrm{kcal} / \mathrm{mol})$

$\begin{array}{llll}\mathrm{C} & 0.32431900 & -5.41105500 & 1.50778400 \\ \mathrm{~N} & 0.31325800 & -4.21518400 & 0.65924400 \\ \mathrm{C} & 0.18938800 & -2.93911500 & 1.22774600 \\ \mathrm{C} & 0.43099300 & -4.35197700 & -0.69878300 \\ \mathrm{~N} & 0.16994100 & -1.86297300 & 0.41363400 \\ \mathrm{~S} & 0.05421200 & -2.78674900 & 2.91748400 \\ \mathrm{C} & 0.41999700 & -3.28379700 & -1.53339400 \\ \mathrm{C} & 0.27485200 & -1.99460600 & -0.92069300 \\ \mathrm{~N} & 0.23881100 & -0.89409500 & -1.68334500\end{array}$




\begin{tabular}{|c|c|c|c|}
\hline $\mathrm{H}$ & 1.16071900 & -5.36869500 & 2.20847700 \\
\hline $\mathrm{H}$ & -0.59874600 & -5.46836800 & 2.08795600 \\
\hline $\mathrm{H}$ & 0.41817400 & -6.28729400 & 0.86362600 \\
\hline $\mathrm{H}$ & 0.52645600 & -3.39801900 & -2.60763000 \\
\hline $\mathrm{H}$ & 0.53526100 & -5.36633700 & -1.06625300 \\
\hline $\mathrm{H}$ & 0.31265200 & -0.99958800 & -2.69043200 \\
\hline $\mathrm{H}$ & 0.15279600 & 0.04440100 & -1.27589100 \\
\hline $\mathrm{N}$ & -0.36625400 & -1.40178100 & -4.74421300 \\
\hline $\mathrm{N}$ & -0.16994100 & 1.86297300 & -0.41363400 \\
\hline $\mathrm{C}$ & 0.48906300 & -1.95588800 & -5.63935700 \\
\hline $\mathrm{C}$ & -1.06017500 & -0.30134700 & -5.02856500 \\
\hline $\mathrm{N}$ & 0.65539500 & -1.31008100 & -6.88176600 \\
\hline $\mathrm{S}$ & 1.34935900 & -3.36487300 & -5.29523400 \\
\hline $\mathrm{C}$ & -0.90268500 & 0.38660900 & -6.27243500 \\
\hline $\mathrm{N}$ & -1.95361000 & 0.13884400 & -4.10538700 \\
\hline $\mathrm{C}$ & 1.58180700 & -1.86133800 & -7.87653000 \\
\hline $\mathrm{C}$ & -0.02737500 & -0.16209700 & -7.15713900 \\
\hline $\mathrm{H}$ & -1.44508800 & 1.29362800 & -6.50580700 \\
\hline $\mathrm{H}$ & -1.88239100 & -0.30123200 & -3.19559700 \\
\hline $\mathrm{H}$ & -2.11517000 & 1.13788700 & -4.05738200 \\
\hline $\mathrm{H}$ & 2.58970900 & -1.91067100 & -7.45960900 \\
\hline $\mathrm{H}$ & 1.27873400 & -2.87505700 & -8.14597400 \\
\hline $\mathrm{H}$ & 1.56792100 & -1.21628600 & -8.75692400 \\
\hline $\mathrm{H}$ & 0.16592300 & 0.28367800 & -8.12610900 \\
\hline $\mathrm{C}$ & -0.18938800 & 2.93911500 & -1.22774600 \\
\hline $\mathrm{C}$ & -0.27485200 & 1.99460600 & 0.92069300 \\
\hline $\mathrm{N}$ & -0.31325800 & 4.21518400 & -0.65924400 \\
\hline S & -0.05421200 & 2.78674900 & -2.91748400 \\
\hline $\mathrm{C}$ & -0.41999700 & 3.28379700 & 1.53339400 \\
\hline $\mathrm{N}$ & -0.23881100 & 0.89409500 & 1.68334500 \\
\hline $\mathrm{C}$ & -0.32431900 & 5.41105500 & -1.50778400 \\
\hline C & -0.43099300 & 4.35197700 & 0.69878300 \\
\hline $\mathrm{H}$ & -0.52645600 & 3.39801900 & 2.60763000 \\
\hline $\mathrm{H}$ & -0.31265200 & 0.99958800 & 2.69043200 \\
\hline $\mathrm{H}$ & -0.15279600 & -0.04440100 & 1.27589100 \\
\hline $\mathrm{H}$ & -1.16071900 & 5.36869500 & -2.20847700 \\
\hline $\mathrm{H}$ & 0.59874600 & 5.46836800 & -2.08795600 \\
\hline $\mathrm{H}$ & -0.41817400 & 6.28729400 & -0.86362600 \\
\hline $\mathrm{H}$ & -0.53526100 & 5.36633700 & 1.06625300 \\
\hline $\mathrm{N}$ & 0.36625400 & 1.40178100 & 4.74421300 \\
\hline $\mathrm{C}$ & -0.48906300 & 1.95588800 & 5.63935700 \\
\hline $\mathrm{C}$ & 1.06017500 & 0.30134700 & 5.02856500 \\
\hline $\mathrm{N}$ & -0.65539500 & 1.31008100 & 6.88176600 \\
\hline S & -1.34935900 & 3.36487300 & 5.29523400 \\
\hline $\mathrm{C}$ & 0.90268500 & -0.38660900 & 6.27243500 \\
\hline $\mathrm{N}$ & 1.95361000 & -0.13884400 & 4.10538700 \\
\hline C & -1.58180700 & 1.86133800 & 7.87653000 \\
\hline $\mathrm{C}$ & 0.02737500 & 0.16209700 & 7.15713900 \\
\hline $\mathrm{H}$ & 1.44508800 & -1.29362800 & 6.50580700 \\
\hline $\mathrm{H}$ & 1.88239100 & 0.30123200 & 3.19559700 \\
\hline $\mathrm{H}$ & 2.11517000 & -1.13788700 & 4.05738200 \\
\hline
\end{tabular}




$\begin{array}{lrrr}\mathrm{H} & -2.58970900 & 1.91067100 & 7.45960900 \\ \mathrm{H} & -1.27873400 & 2.87505700 & 8.14597400 \\ \mathrm{H} & -1.56792100 & 1.21628600 & 8.75692400 \\ \mathrm{H} & -0.16592300 & -0.28367800 & 8.12610900\end{array}$

